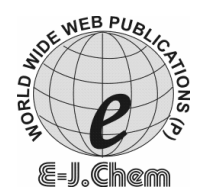

\title{
Corrosion Inhibition of Mild Steel in Hydrochloric Acid by 2-Benzoylpyridine and Pyridoxolhydrochloride
}

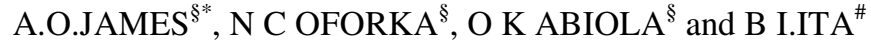 \\ ${ }^{\S}$ Department of Pure and Industrial Chemistry, \\ University of Port Harcourt, P.M.B. 5323, Port Harcourt, Nigeria. \\ ${ }^{\#}$ Chemistry Department, University of Calabar, Calabar, Nigeria. \\ bidean2002@yahoo.com
}

Received 1 July 2008; Revised 24 October 2008; Accepted 10 December 2008

\begin{abstract}
The inhibition of corrosion of mild steel in hydrochloric acid solutions by 2-benzoylpyridine (2BP) and pyridoxolhydrochloride (PXO) at $303 \mathrm{~K}, 313 \mathrm{~K}$ and $323 \mathrm{~K}$ has been investigated using weight loss and hydrogen evolution techniques. 2BP exhibited higher maximum inhibition efficiency (78.99\%) than PXO (71.93\%). Generally inhibition was found to increase with increasing inhibitor concentration and decreasing temperature. A first order type of mechanism has been deduced from the kinetic treatment of the results and the process of inhibition was attributed to physisorption. The difference in the inhibition behaviour of the two compounds has been explained on the basis of structure dependent electron donor properties of the inhibitors.
\end{abstract}

Keywords: Corrosion inhibition; 2-Benzoylpyridine; Pyridoxolhydrochloride.

\section{Introduction}

The serious consequences of corrosion tend to jeopardize safety and inhibit technology progress because of the vital role of metal to the world economy ${ }^{1}$. The continuous painting of steel structures reveals that corrosion of steel is an ever increasing problem ${ }^{2}$. The inhibition of steel corrosion has continued to pose a lot of problems for scientists and engineers ${ }^{3}$. Several $N$ - and $S$ - containing organic compounds have been employed as inhibitors for the corrosion of mild steel in hydrochloric acid solutions at certain concentrations and temperatures ${ }^{4-7}$. This present investigation is aimed at studying the inhibition of mild steel corrosion in hydrochloric acid by 2-benzoylpyridine and pyridoxol hydrochloride via weight loss and hydrogen evolution techniques (gasometric assembly). 
The weight loss method enables us to illustrate the importance of the environment in the process of rusting while the hydrogen evolution technique allows us to assess the effectiveness of the inhibitors at high corrodent concentration (up to $8 \mathrm{M}$ ). The relevant equation used in the calculation of inhibition efficiency, I (\%) has the form:

$$
\% \text { Inhibition Efficiency }=\frac{\Delta W_{B}-\Delta W_{i}}{\Delta W_{B}} \times \frac{100}{1}
$$

Where, $\Delta \mathrm{W}_{\mathrm{B}}$ and $\Delta \mathrm{W}_{\mathrm{i}}$ are the weight loss (or hydrogen gas evolution) data of metal coupons in the absence and presence of the inhibitors respectively. This study is a continuation of our extensive studies on the efficiency of pyridoxolhydrochloride as potential corrosion inhibitors ${ }^{7}$.

\section{Experimental}

The sheets of mild steel obtained locally and of thickness $1.00 \mathrm{~mm}$, purity $98.76 \%$ were mechanically press-cut into $5 \times 2 \mathrm{~cm}$ coupons. The two faces had $20.0 \mathrm{~cm}^{2}$ total geometric surface areas. The average weight of the mild steel is $7.5000-7.8700 \mathrm{~g}$.

The coupons were used as supplied without further polishing. However, these coupons were degreased in absolute ethanol, rinsed with double distilled water and dried in acetone. The treated coupons were then stored over calcium chloride in moisture free desiccators before use for corrosion studies to prevent contamination. The 2-benzoylpyridine used as inhibitor was supplied by Aldrich-Chemie while pyridoxolhydrochloride, by E.Marck Darmstadt. Both were of $99.0 \%$ purity.

\section{Weight loss measurements}

Fifteen $250 \mathrm{~mL}$ beakers, which separately contained 1.0, 2.0, 3.0, 4.0 and 5.0 $\mathrm{M} \mathrm{HCl}$ were maintained at 30,40 and $50{ }^{\circ} \mathrm{C}$ constituting three sets of experiments. Previously weighed mild steel coupons were each suspended in each beaker through a $0.1 \mathrm{~cm}$ hole in diameter. The mild steel coupons in $\mathrm{HCl}$ solutions at 30,40 and $50{ }^{\circ} \mathrm{C}$ were retrieved at $24 \mathrm{~h}$ interval progressively for $168 \mathrm{~h}$ (7days).

The mild steel coupons retrieved were immersed in a solution of $20 \%$ sodium hydroxide containing $200 \mathrm{~g} /$ litre of $\mathrm{Zn}$ dust to terminate the corrosion reaction. Each coupon was scrubbed with brittle brush, several times inside water to remove corrosion product, dried in ethanol and acetone and then weighed.

The weight loss was calculated in grams as the difference between the initial weight prior to immersion and weight after removal of the corrosion product. Each reading reported is an average of two readings recorded to the nearest $0.0001 \mathrm{~g}$ on a mettler AE 166 Delta range analytical balance.

The second segment of the corrosion work involved the preparation of five different concentrations $\left(1.0 \times 10^{-2}, 1.0 \times 10^{-3}, 1.0 \times 10^{-4}, 1.0 \times 10^{-5}\right.$ and $\left.1.0 \times 10^{-6} \mathrm{M}\right)$ of $2 \mathrm{BP}$ and PXO in $2 \mathrm{M} \mathrm{HCl}$ solutions. These concentrations of the inhibitors were contained in three sets of six separate beakers kept at 30,40 and $50{ }^{\circ} \mathrm{C}$. Eighteen $250 \mathrm{~mL}$ beakers which are separately contained $1.0 \times 10^{-2}$ to $1.0 \times 10^{-6} \mathrm{M}$ concentrations of $2 \mathrm{BP}$ and $\mathrm{PXO}$ with their blank (which only contained $2 \mathrm{M} \mathrm{HCl}$ without additives were maintained at 30,40 and $50{ }^{\circ} \mathrm{C}$. Previously weighed mild steel coupons were then placed in the corrodent inhibitor solutions with each solution containing one mild steel coupon. As before, each coupon was retrieved from the test solutions at $24 \mathrm{~h}$ intervals progressively for $168 \mathrm{~h}$ (7 days), washed and weighed. The difference in weight of the coupons was again taken as the weight loss. 


\section{Hydrogen evolution measurement, via the gasometric assembly}

The gasometric assembly ${ }^{8}$ was used in measuring volumes of hydrogen gas evolution from the corrosion reaction system. A $250 \mathrm{~mL}$ solution of $8 \mathrm{M} \mathrm{HCl}$ was introduced into the reaction vessel connected to a burette through a delivery tube. The initial volume of air in the burette was recorded. One mild steel coupon of average weight of $7.8 \mathrm{~g}$ was dropped into the $8 \mathrm{M} \mathrm{HCl}$ solution and the reaction vessel quickly closed to prevent escape of hydrogen gas.

Variation in the volume of hydrogen gas evolved with time was recorded every 1 minute for $2 \mathrm{~h}$. Each experiment was conducted on a fresh specimen of metal coupon. The hydrogen gas evolved displaced the fluid in the gasometric setup, which is read directly. The experiment was repeated in the presence of the five different concentrations of $2 \mathrm{BP}$ and PXO, $1.0 \times 10^{-2}$ to $1.0 \times 10^{-6} \mathrm{M}$ as used in the weight loss experiments.

\section{Results and Discussion}

Effect of corrodent concentration on mild steel corrosion

The influence of corrodent concentration on mild steel corrosion is shown in Figure 1.

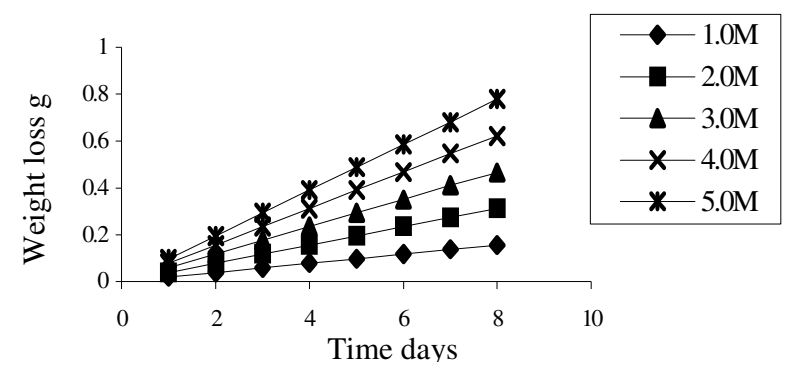

Figure 1. Variation of weight loss (g) of mild steel with time (days) for different concentrations of $\mathrm{HCl}$ solution at $30^{\circ} \mathrm{C}$.

It is observed that mild steel corrode in different concentration of $\mathrm{HCl}$ solutions, because there is a decrease in original weight of the coupons. The corrosion is attributed to the presence of water, air and $\mathrm{H}^{+}$, which accelerate the corrosion process ${ }^{9}$. The anode dissolution mild steel in $\mathrm{HCl}$ solutions is as follows:

$$
\mathrm{Fe} \rightarrow \mathrm{Fe}^{2+}+2 \mathrm{e}^{-}
$$

The dissolution is initiated at the surface of the metal, which is the reaction site. The plots of corrosion rates ( $\left.\mathrm{glcm}^{2} \mathrm{lday}\right)$ versus concentration of $\mathrm{HCl}$ solutions as exhibited in Figure 2 buttressed the fact that the corrosion rate $\left(\mathrm{g} / \mathrm{cm}^{2}\right.$ lday) increased with corrodent concentration and time.

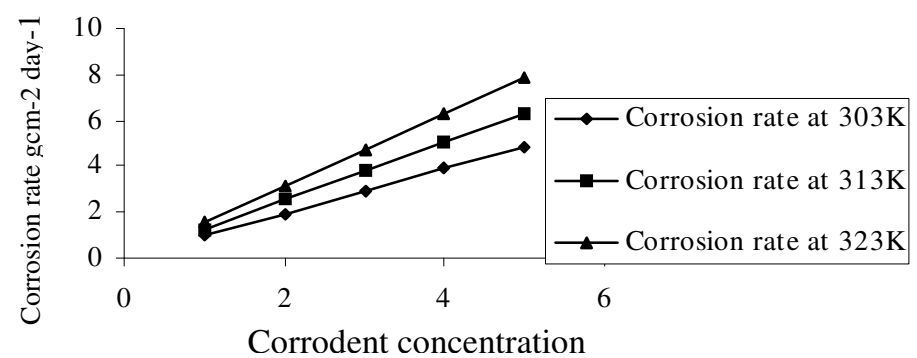

Figure 2. Variation of corrosion rate $\left(\mathrm{gcm}^{-2} \mathrm{day}^{-1}\right)$ with corrodent concentration (M) for mild steel coupons in $\mathrm{HCl}$ solution at different temperatures without inhibitor. 
Similar observation and appropriate explanation was given by earlier researchers ${ }^{2,6,9}$.

\section{Effect of temperature on the corrosion of mild steel by $\mathrm{HCl}$ solution}

The effect of temperature on the corrosion of the metals was investigated and presented in the Figure 2 and 3.
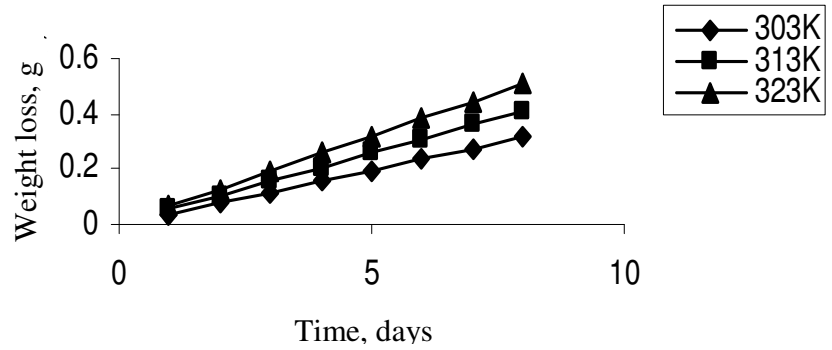

Figure 3. Variation of weight loss (g) with time (days) for mild steel coupons in $2 \mathrm{M} \mathrm{HCl}$ solutions at different temperatures without inhibitor.

There is a progressive increase in weight loss as the temperature is increased from 303 to $323 \mathrm{~K}$. This signifies that the dissolution of the metals increased at higher temperatures.

This observation is attributed to the general rule guiding the rate of chemical reaction, which says that chemical reaction increases with increasing temperatures. Also an increased temperature favors the formation of activated molecules, which may be doubled in number, with $10{ }^{\circ} \mathrm{C}$ in temperature, thereby increasing the reaction rate. This is because the reactant molecules gain more energy and are able to overcome the energy barrier more rapidly ${ }^{11}$. The increase in weight loss with increasing temperatures may also be due to increase in the rate of diffusion and ionization of reacting species in the corrosion process, as temperature increases. An increase in temperature may also increase the solubility of the protective films on the metals, thus increasing the susceptibility of the metal to corrosion ${ }^{6}$.

\section{Effect of inhibitors concentration on inhibition efficiency}

Figures 4-7 reveal that the compounds 2 BP and PXO actually inhibit the corrosion of mild steel in $\mathrm{HCl}$ solutions to a remarkable extent. Inhibition efficiency was observed from the plots to increase with increased inhibitor concentration but with decreased temperature.

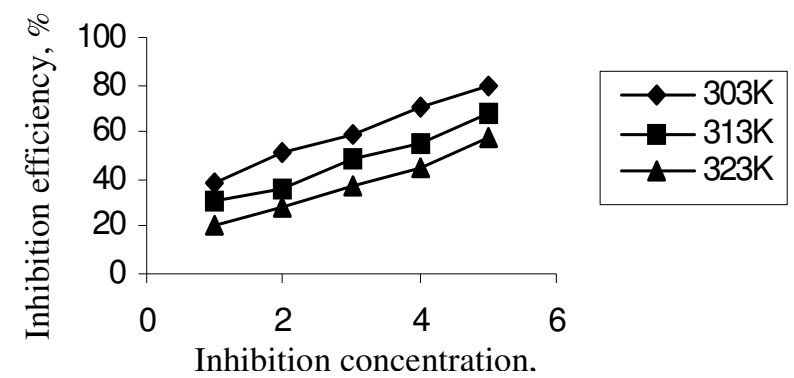

Figure 4. Variation of inhibition efficiency (\%) with inhibitor concentration (M) for mild steel coupons in $2 \mathrm{M} \mathrm{HCl}$ solutions containing 2-benzoylpyridine at different temperatures. 

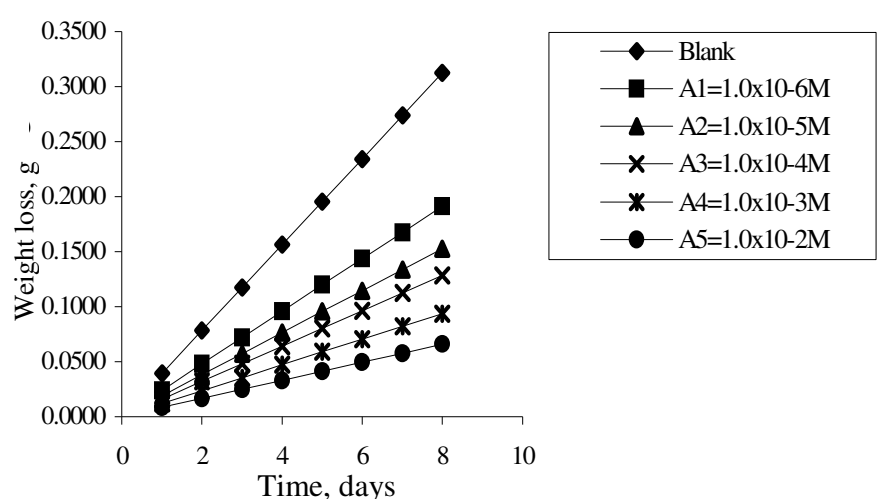

Time, days

Figure 5. Variation of weight loss (g) with time (days) for mild steel coupons in $2 \mathrm{M} \mathrm{HCl}$ solutions containing 2-benzoylpyridine at $303 \mathrm{~K}$.

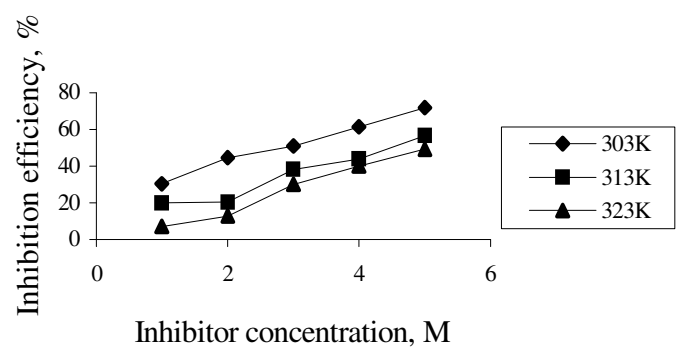

Figure 6. Variation of inhibition efficiency (\%) with inhibitor concentrations (M) for mild steel coupons in $2 \mathrm{M} \mathrm{HCl}$ solution containing pyridoxolhydrochloride at different temperatures.

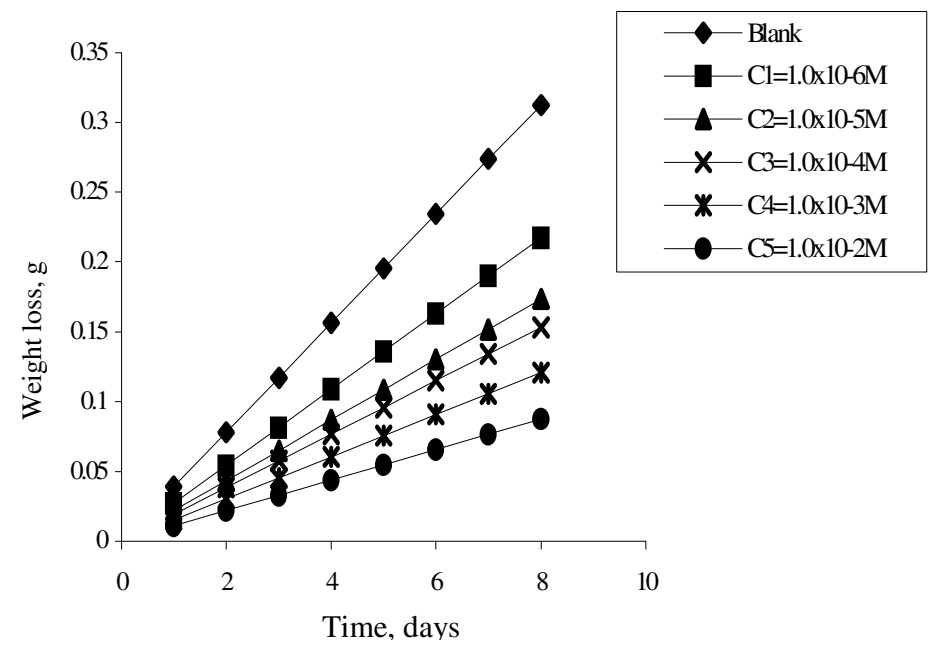

Figure 7. Variation of weight loss (g) with time (days) for mild steel coupons in $2 \mathrm{M} \mathrm{HCl}$ solution containing different concentrations of pyridoxolhydrochloride at $303 \mathrm{~K}$.

The corrosion rate of the metal decreases with increase in the concentration of the additives. 
Hydrogen evolution results via the gasometric assembly

The general decrease in hydrogen gas evolution with time as concentration of additives increased from $0.00001 \mathrm{M}$ to $0.01 \mathrm{M}$ (Figures 8 and 9 ) confirm that the inhibition efficiency increases with concentration of the additives. Similar observation has been reported earlier ${ }^{9,10}$.

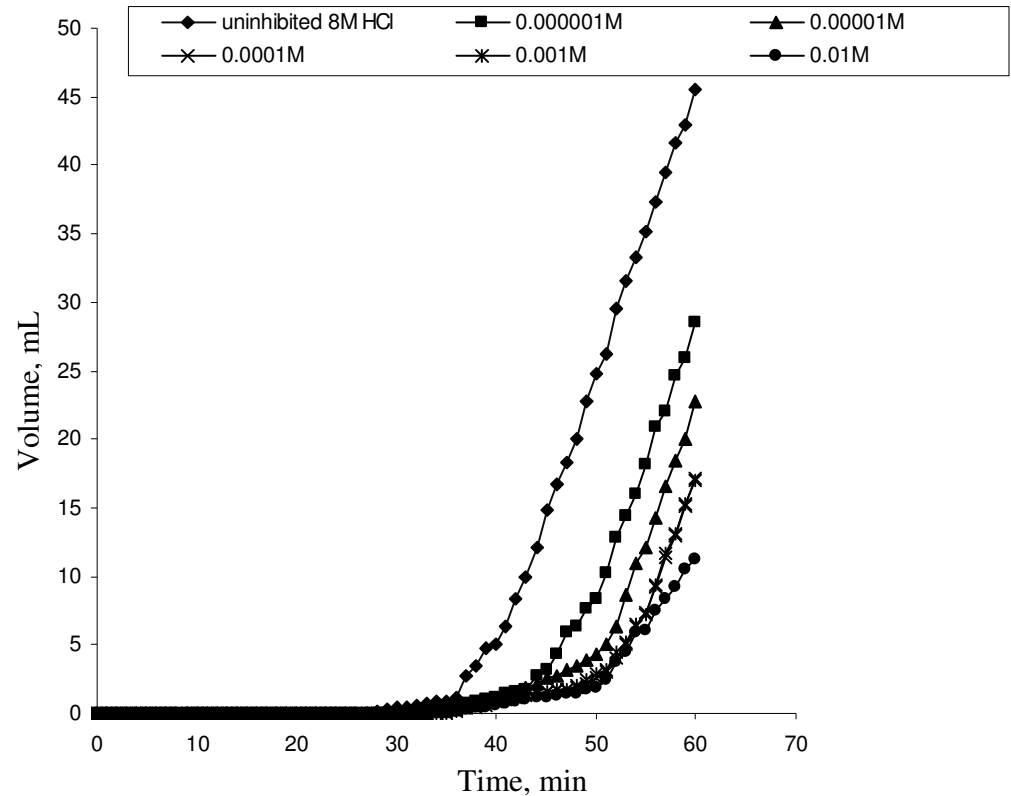

Figure 8. Variation of volume of hydrogen gas evolved with time (min) for the inhibition of mild steel in $8 \mathrm{M} \mathrm{HCl}$ solutions by 2-benzoylpyridine at $303 \mathrm{~K}$.

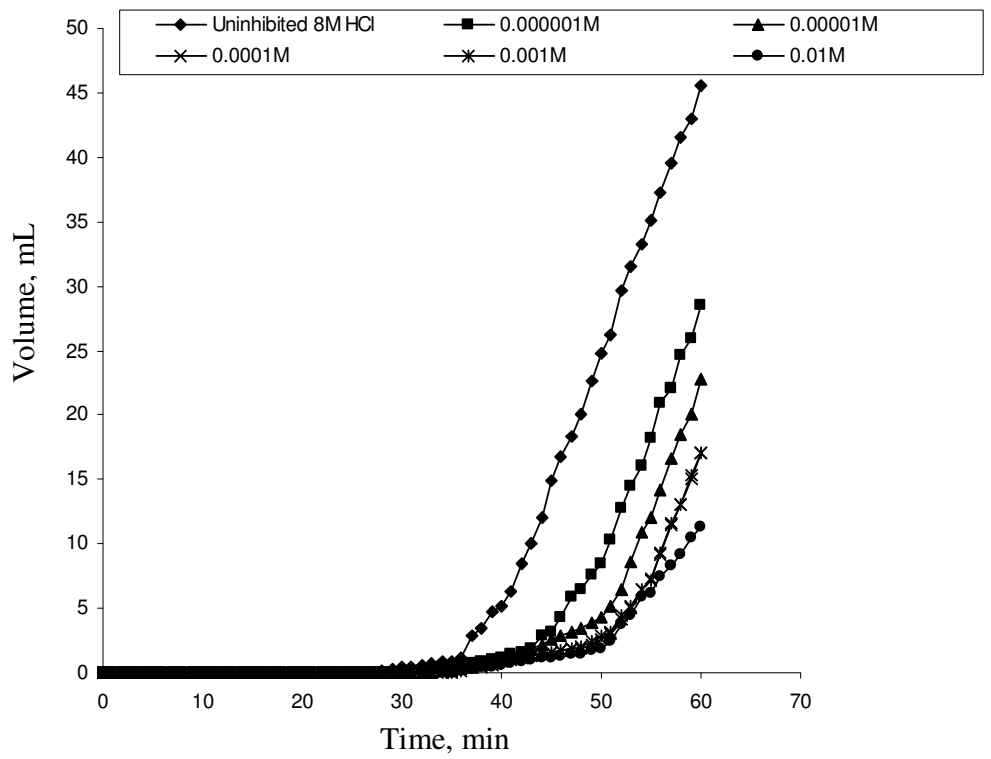

Figure 9. Variation of volume of hydrogen gas evolved with time (min) for the inhibition of mild steel in $8 \mathrm{M} \mathrm{HCl}$ solutions by pyridoxolhydrochloride at $303 \mathrm{~K}$. 
Kinetic treatment of weight loss results

The corrosion reaction is a heterogeneous one, composed of anodic and cathodic reactions with the same or different rate. It is on this basis that kinetic analysis of the data is considered necessary.

In this present study, the initial weight of mild steel coupon at time $\mathrm{t}$, is designated $\mathrm{Wi}$, the weight loss is $\Delta \mathrm{W}$ and the weight change at time $\mathrm{t}$, (Wi $-\Delta \mathrm{W})$. The plots of log (Wi$\Delta \mathrm{W}$ ) against time (min) at $303 \mathrm{~K}$ and other temperatures studied, showed a linear variation which confirms a first order reaction kinetics with respect to the corrosion of mild steel in $\mathrm{HCl}$ solutions at $303 \mathrm{~K}$ without inhibitor (Figure 10).

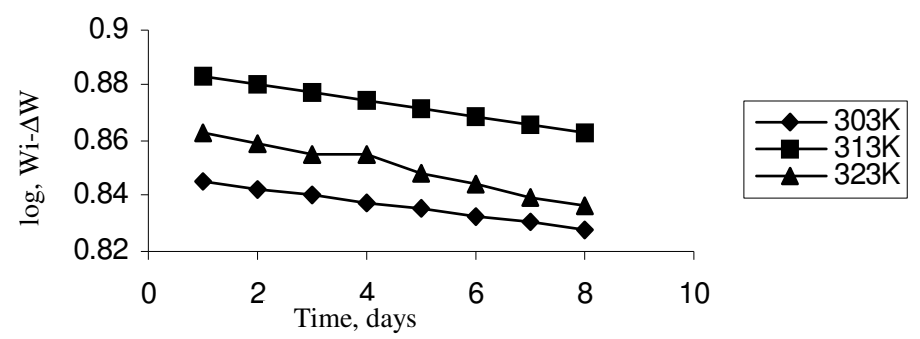

Figure 10. Variation of $\log (\mathrm{Wi}-\Delta \mathrm{W})$ with time (days) for mild steel coupons in $2 \mathrm{M} \mathrm{HCl}$ solution at different temperatures without inhibitor.

Figures 11 and 12 show a linear plot, suggesting a first order reaction kinetics with respect to mild steel corrosion in $2 \mathrm{M} \mathrm{HCl}$ solutions in the presence of the additives.

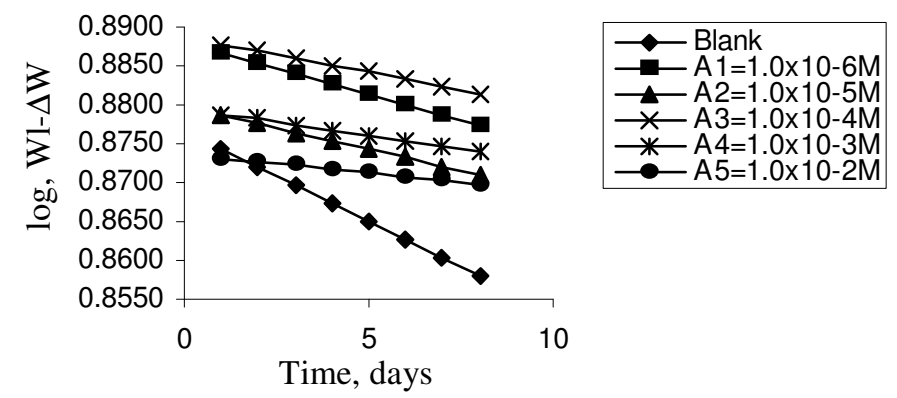

Figure 11. Variation of $\log (\mathrm{Wi}-\Delta \mathrm{W})$ with time (days) for mild steel coupons in $2 \mathrm{M} \mathrm{HCl}$ solution containing 2-benzoylpyridine at $303 \mathrm{~K}$.

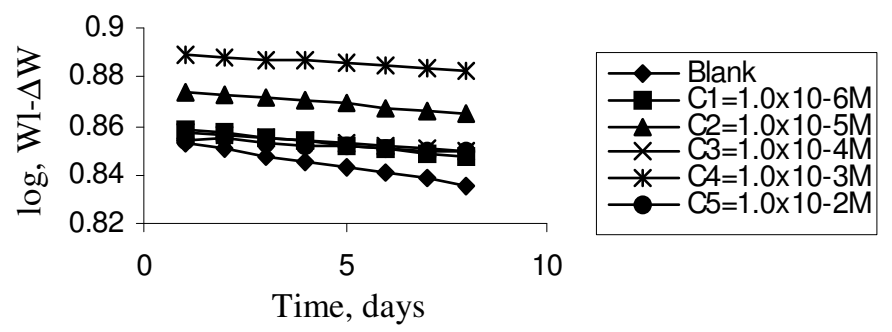

Figure 12. Variation of $\log (\mathrm{Wi}-\Delta \mathrm{W})$ with time (days) for mild steel coupons in $2 \mathrm{M} \mathrm{HCl}$ solutions containing different concentration of pyridoxolhydrochloride at $303 \mathrm{~K}$. 
Table 1. Kinetic data for mild steel in different concentrations of hydrochloric acid solution without additives (Inhibitor).

\begin{tabular}{ccccccccc}
\hline $\begin{array}{c}\text { Hydrochloride acid } \\
\text { concentration, } \mathrm{M}\end{array}$ & $\begin{array}{c}\text { Rate Constant, } \\
\mathrm{K} \text {, day }{ }^{-1} \times 10^{-3}\end{array}$ & \multicolumn{3}{c}{$\begin{array}{c}\text { Half-Life, } \\
\mathrm{t}_{1 / 2} \text {, days } \times 10^{2}\end{array}$} & $\begin{array}{c}\text { Activation } \\
\text { Energy kJmo1 }{ }^{-1}\end{array}$ & $\begin{array}{c}\text { Average Activation } \\
\text { Energy kJmo }{ }^{-1}\end{array}$ \\
\cline { 2 - 8 } & $303 \mathrm{~K}$ & $313 \mathrm{~K}$ & $323 \mathrm{~K}$ & $303 \mathrm{~K}$ & $323 \mathrm{~K}$ & $323 \mathrm{~K}$ & & \\
\hline 1.0 & 2.69 & 3.53 & 4.48 & 2.58 & 1.96 & 1.55 & 21.43 & \\
2.0 & 5.63 & 6.81 & 8.88 & 1.23 & 1.02 & 0.78 & 15.01 & \\
3.0 & 7.90 & 10.42 & 12.94 & 0.88 & 0.67 & 0.54 & 21.83 & \\
4.0 & 10.83 & 14.19 & 19.35 & 0.64 & 0.49 & 0.36 & 21.31 & \\
5.0 & 13.33 & 17.43 & 22.05 & 0.52 & 0.40 & 0.31 & 21.15 & \\
\hline
\end{tabular}

Table 2. Kinetic data for mild steel in $2 \mathrm{M} \mathrm{HCl}$ containing 2-benzoylpyridine from weight loss measurement.

\begin{tabular}{|c|c|c|c|c|c|c|c|c|c|}
\hline \multirow[t]{2}{*}{$\begin{array}{c}\text { Inhibitor } \\
\text { Concentration, } \mathrm{M}\end{array}$} & \multicolumn{2}{|c|}{$\begin{array}{l}\text { Rate Constant, } \mathrm{K}, \\
\text { day }^{-1} \times 10^{-3}\end{array}$} & \multicolumn{3}{|c|}{$\begin{array}{l}\text { Half-life, } \mathrm{t}_{1 / 2}, \\
\text { days } \times 10^{2}\end{array}$} & \multicolumn{2}{|c|}{$\begin{array}{c}\text { Activation } \\
\text { Energy kJmo1 }^{-1}\end{array}$} & \multicolumn{2}{|c|}{$\begin{array}{l}\text { Average Activation } \\
\text { Energy kJmo1 }^{-1}\end{array}$} \\
\hline & $303 \mathrm{~K} 313 \mathrm{~K}$ & $323 \mathrm{~K}$ & $303 \mathrm{~K}$ & $313 \mathrm{~K}$ & $323 \mathrm{~K}$ & $\begin{array}{l}303 \mathrm{~K}- \\
313 \mathrm{~K}\end{array}$ & $\begin{array}{l}313 \mathrm{~K}- \\
323 \mathrm{~K}\end{array}$ & $\begin{array}{l}303 \mathrm{~K}- \\
313 \mathrm{~K}\end{array}$ & $\begin{array}{l}313 \mathrm{~K}- \\
323 \mathrm{~K}\end{array}$ \\
\hline $1.0 \times 10^{-6}$ & 3.114 .37 & 6.96 & 2.23 & 1.59 & 1.00 & 26.82 & 39.13 & & \\
\hline $1.0 \times 10^{-5}$ & $2.54 \quad 4.31$ & 6.30 & 2.73 & 1.61 & 1.10 & 41.70 & 31.91 & & \\
\hline $1.0 \times 10^{-4}$ & $2.09 \quad 3.54$ & 5.75 & 3.32 & 1.96 & 1.21 & 41.56 & 40.78 & 44.08 & 36.85 \\
\hline $1.0 \times 10^{-3}$ & $1.55 \quad 3.03$ & 4.62 & 4.47 & 2.29 & 1.50 & 52.86 & 35.46 & & \\
\hline $1.0 \times 10^{-2}$ & $1.10 \quad 2.28$ & 3.54 & 6.30 & 3.04 & 1.96 & 57.48 & 36.99 & & \\
\hline
\end{tabular}

Table 3. The kinetic data for mild steel in $2 \mathrm{M} \mathrm{HCl}$ solution containing pyridoxol hydrochloride at different temperatures.

\begin{tabular}{|c|c|c|c|c|c|c|c|c|c|c|}
\hline \multirow[t]{2}{*}{$\begin{array}{c}\text { Inhibitor } \\
\text { Concentration, } \mathrm{M}\end{array}$} & \multicolumn{3}{|c|}{$\begin{array}{l}\text { Rate Constant, } \\
\mathrm{K}, \text { day }^{-1} \times 10^{-3}\end{array}$} & \multicolumn{3}{|c|}{$\begin{array}{l}\text { Half-Life, } \\
\mathrm{t}_{1 / 2}, \text { days } \times 10^{2}\end{array}$} & \multicolumn{2}{|c|}{$\begin{array}{c}\text { Activation } \\
\text { Energy kJ mo1 }^{-1}\end{array}$} & \multicolumn{2}{|c|}{$\begin{array}{l}\text { Average Activation } \\
\text { Energy kJ mol }{ }^{-1}\end{array}$} \\
\hline & $303 \mathrm{~K}$ & $313 \mathrm{~K}$ & $323 \mathrm{~K}$ & $303 \mathrm{~K}$ & $313 \mathrm{~K}$ & $323 \mathrm{~K}$ & $\begin{array}{l}303 \mathrm{~K}- \\
313 \mathrm{~K}\end{array}$ & $\begin{array}{l}313 \mathrm{~K}- \\
323 \mathrm{~K}\end{array}$ & $\begin{array}{l}303 \mathrm{~K}- \\
313 \mathrm{~K}\end{array}$ & $\begin{array}{l}313 \mathrm{~K}- \\
323 \mathrm{~K}\end{array}$ \\
\hline $1.0 \times 1$ & 3.78 & 6.09 & 8.41 & 1.83 & 1.14 & 0.82 & 37.61 & 27.15 & & \\
\hline $1.0 \times 1$ & 2.91 & 5.81 & 7.83 & 2.38 & 1.19 & 0.8 & & & & \\
\hline $1.0 \times 1$ & 2.67 & 4.44 & 5.85 & 2.60 & 1.56 & 1.18 & 40.11 & 23.19 & 50.04 & 23.89 \\
\hline $1.0 \times 10^{-3}$ & 1.96 & 4.17 & 5.24 & 3.54 & 1.66 & 1.32 & 59.54 & 19.20 & & \\
\hline $1.0 \times 10^{-2}$ & 1.54 & 3.23 & 4.34 & 4.50 & 2.15 & 1.60 & 58.41 & 24.83 & & \\
\hline
\end{tabular}

Comparison of the corrosion inhibition behaviour of the inhibitors studied

There is a general decrease in the rate constants from $303 \mathrm{~K}$ - $323 \mathrm{~K}$ with increasing concentrations of the additives (Table 4 and 5). The increase in half-life $\left(t_{1 / 2}\right)$ shown when the additives are present further supports the inhibition of mild steel in $2 \mathrm{M} \mathrm{HCl}$ by the additives. The increase in half life indicates more protection of the metals by the additives ${ }^{11}$. The average activation energies of $50.04 \mathrm{~kJ} \mathrm{~mol}^{-1}$ and $44.08 \mathrm{~kJ} \mathrm{~mol}^{-1}$ were obtained in the $\mathrm{HCl}-\mathrm{PXO}$ and $\mathrm{HCl}-2 \mathrm{BP}$ systems respectively at $303-313 \mathrm{~K}$. On the basis of these experimentally determined activation energy values, the additives are physically adsorbed on the coupons. Therefore, it is probable that a multilayer protective coverage on the entire mild steel surface was obtained. 
Table 4. The inhibition efficiency (\%) for mild steel corrosion in $2 \mathrm{M} \mathrm{HCl}$ solution by pyridoxolhydrochloride at different temperatures.

\begin{tabular}{cccc}
\hline \multirow{2}{*}{$\begin{array}{c}\text { Inhibitor } \\
\text { Concentration, } \mathrm{M}\end{array}$} & \multicolumn{3}{c}{ Inhibitor Efficiency, \% } \\
\cline { 2 - 4 } & $303 \mathrm{~K}$ & $313 \mathrm{~K}$ & $323 \mathrm{~K}$ \\
\hline $1.0 \times 10^{-6}$ & 30.41 & 19.90 & 7.26 \\
$1.0 \times 10^{-5}$ & 44.49 & 20.33 & 12.82 \\
$1.0 \times 10^{-4}$ & 50.94 & 38.23 & 30.08 \\
$1.0 \times 10^{-3}$ & 61.34 & 43.83 & 40.01 \\
$1.0 \times 10^{-2}$ & 71.93 & 56.62 & 49.14 \\
\hline
\end{tabular}

Table 5. The inhibition efficiency (\%) for mild steel corrosion in $2 \mathrm{M} \mathrm{HCl}$ solution by 2 benzoylpyridine at different temperatures.

\begin{tabular}{cccc}
\hline \multirow{2}{*}{$\begin{array}{c}\text { Inhibitor } \\
\text { Concentration, M }\end{array}$} & \multicolumn{3}{c}{ Inhibitor Efficiency, \% } \\
\cline { 2 - 4 } & $303 \mathrm{~K}$ & $313 \mathrm{~K}$ & $323 \mathrm{~K}$ \\
\hline $1.0 \times 10^{-6}$ & 38.82 & 30.60 & 20.22 \\
$1.0 \times 10^{-5}$ & 51.27 & 35.63 & 28.58 \\
$1.0 \times 10^{-4}$ & 58.95 & 48.22 & 36.93 \\
$1.0 \times 10^{-3}$ & 69.77 & 55.33 & 45.15 \\
$1.0 \times 10^{-2}$ & 78.99 & 67.55 & 58.13 \\
\hline
\end{tabular}

The inhibitors are found to be more effective at $303 \mathrm{~K}$ (lower temperature) than $313 \mathrm{~K}$ and $323 \mathrm{~K}$ (higher temperatures), signifying that the compounds are physically adsorbed on the mild steel coupons.

The inhibitive effect of the inhibitors may be explained by considering the adsorption of the molecules through the heterocyclic nitrogen of the pyridine, available electron rich oxygen and complex formation (surface chelation) on the corroding metal surface. It is evident that the inhibition efficiency of 2BP and PXO depends mainly on the molecular size of the compounds, the charge density on the adsorption sites, $\pi$ electron clouds, mode of interaction with the metal surface and formation of metallic complexes.

It is observed from the results (Table 6 and 7) that 2BP is more inhibitive than PXO. This observation could be attributed to the presence of two adsorption centres (the heterocyclic nitrogen atom, and the carbonyl oxygen atom) in the 2BP while PXO has only the heterocyclic nitrogen as the adsorption site (Figure 13 and 14). Electrons are pulled from the benzene ring on the oxygen atom of the benzoyl group giving it higher electron density than PXO.<smiles>CCOCCOCCOCc1ncc(CO)c(CO)c1O</smiles>

Figure 13. Structure of Pyridoxol hydrochloride. 
2BP could also been inhibiting more due to the presence of the two benzoyl groups which increase its molecular size leading to a larger surface coverage. The effectiveness of 2BP also appears to depend on the high charged density on the $\mathrm{N}$ and $\mathrm{O}$-adsorption sites due to the availability of the $\pi$ electron clouds from the two benzene rings contained in the molecule (Figure 14).

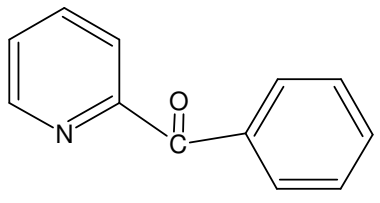

2- Benzoylpyridine

\section{Conclusion}

Figure 14. Stucture of 2-benzoylpyridine

The present study shows that $2 \mathrm{BP}$ and PXO inhibit the corrosion of mild steel in $2 \mathrm{M}$ hydrochloric solution to a remarkable degree, with the former being a better inhibitor than the latter. On the basis of activation energy and the experimentally observed increase in inhibition at low temperatures, a physiosorption process is proposed for the inhibitor action of the two compounds.

\section{Acknowledgement}

The authors are thankful to Professor Offiong E. Offiong of University of Calabar, Nigeria for providing one of the inhibitors, 2-Benzoyl pyridine, used for this study.

\section{References}

1. Abiola O K and Oforka N C, J Corr Sci Eng., 2002, 3(21), 117-124.

2. Ita B I and Edem C A, Global J Pure Appl Sci., 2000, 6(2), 239 -242.

3. Ita B I and Offiong O E, Mater Chem Phys., 1999, 59, 179-184.

4. Ebenso E E, Okafor P C and Ekpe U J, Bull Electrochem., 2002, 18(12), 551-558.

5. James A O, Oforka N C and Abiola O K, Bull Electrochem.. 2006, 22(3), 111-116.

6. Okafor I P C, Ebenso E E and Ekpe U, J Bull Chem Soc., Ethiopia, 2004, 18(12), 181-192.

7. James A O, Oforka N C and Abiola O K, J Corr Sci Eng., 2005, 7(21), 1-10.

8. Onuchukwu A I, Mater Chem Phys., 1990, 24, 331-341.

9. Orubite K O and Oforka N C, Mat Lett., 2004, 58, 1768-1772.

10. Talati J D and Daraji J M, J Indian Chem Soc., 1991, 68, 67-72.

11. Ita B I, Bull Electrochem., 2004, 20(8), 363-370. 


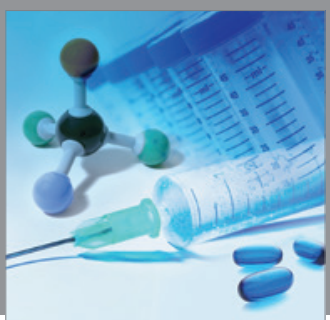

International Journal of

Medicinal Chemistry

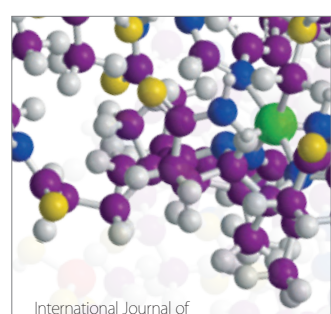

Carbohydrate Chemistry

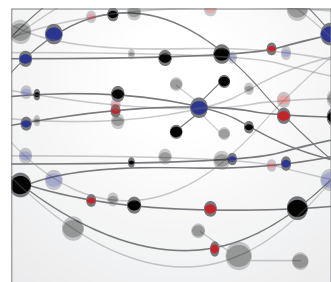

The Scientific World Journal
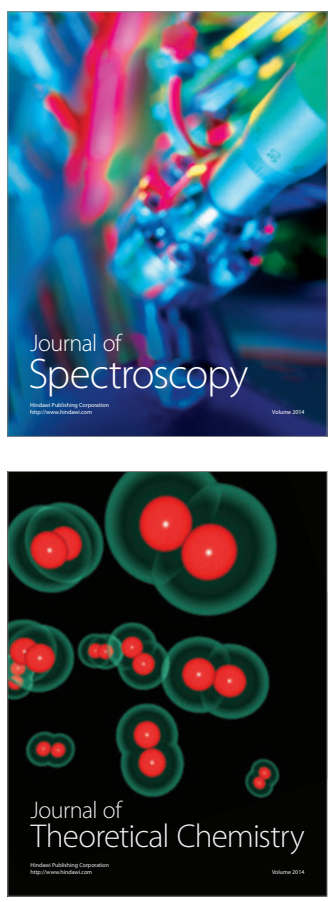
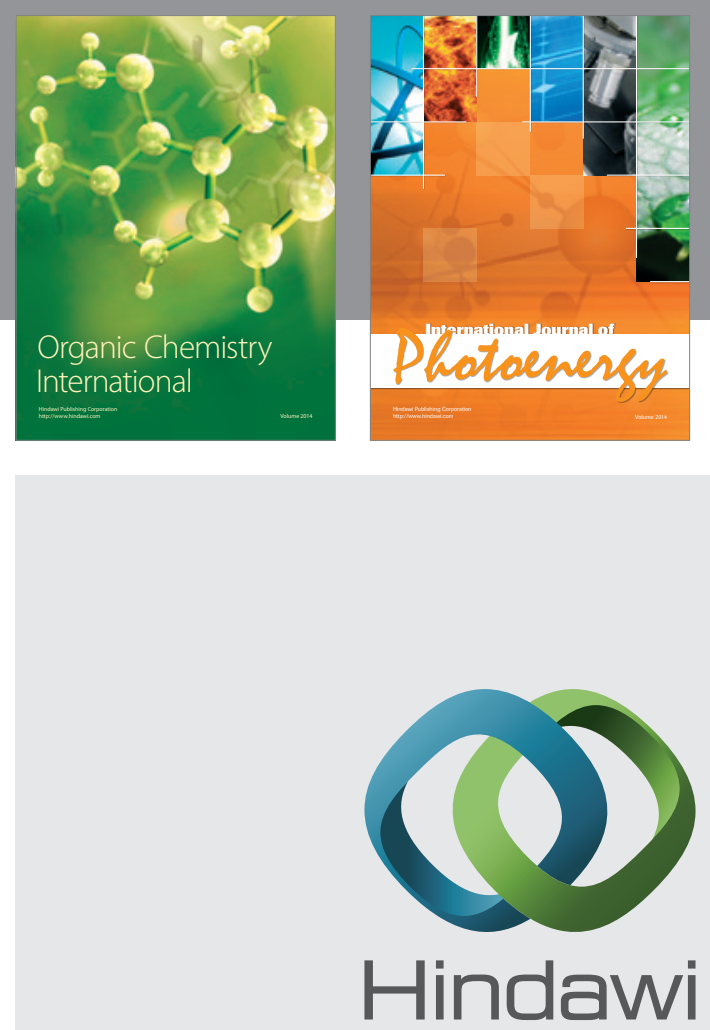

Submit your manuscripts at

http://www.hindawi.com
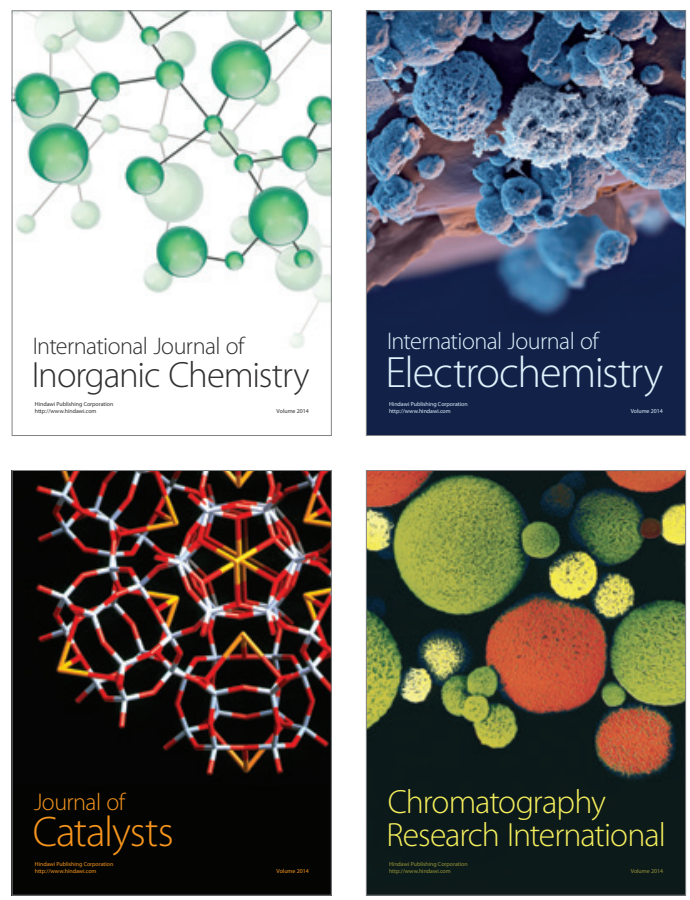
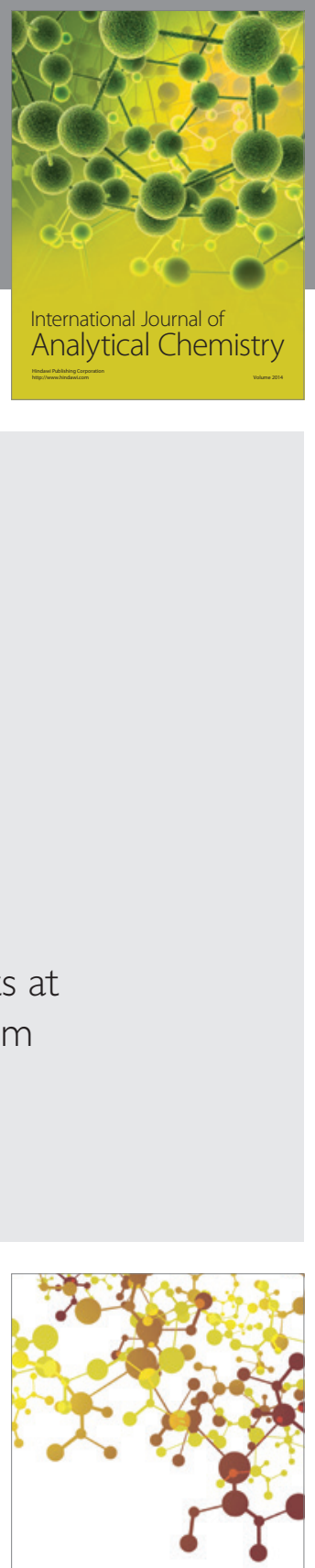

Journal of

Applied Chemistry
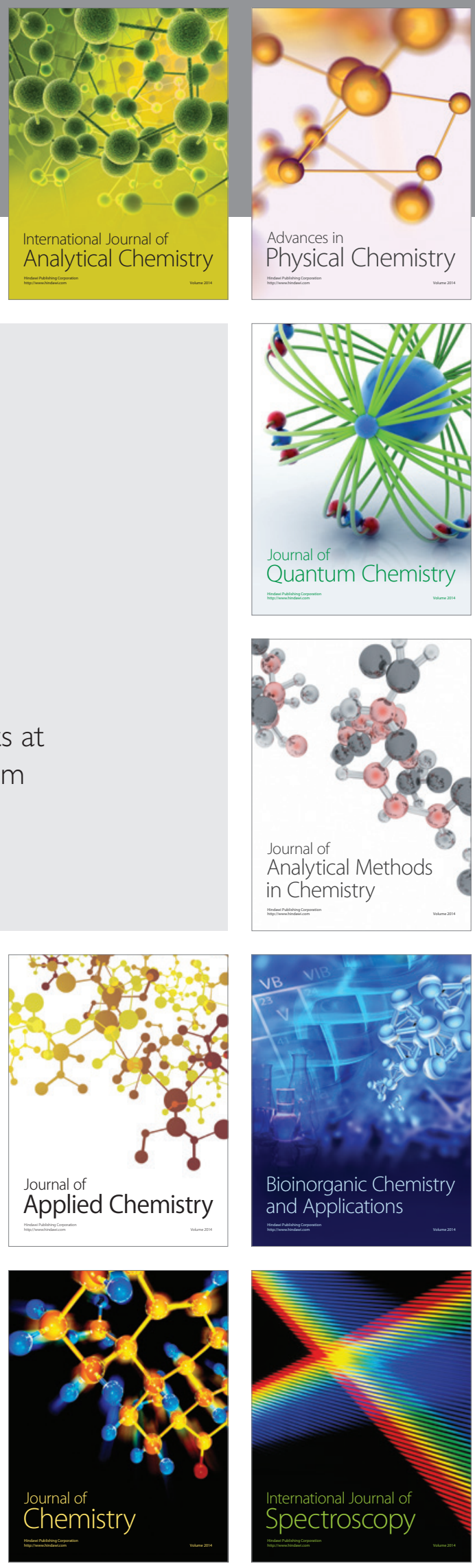